\title{
Asylum Seekers and the Labour Market: Spaces of Discomfort and Hostility
}

\section{Louise Waite}

School of Geography, University of Leeds

E-mail: L.Waite@leeds.ac.uk

This article examines the relationship in the UK between asylum-seeking and the labour market. Since 2002, asylum-seekers have not been allowed to work unless they have waited over twelve months for an initial decision on their asylum claim. This policy change occurred as employment was considered a 'pull factor' encouraging unfounded asylum claims. Despite not having the right to work, asylum-seekers - and especially those whose applications for refugee status have been refused by the UK government - interact with the labour market in manifold ways. Drawing on an ESRC-funded study in the UK's Yorkshire and Humber region and related studies, this article argues that both asylumseekers and refused asylum-seekers form a hyper-exploitable pool of 'illegalised' and unprotected workers. As a vital part of their survival terrain, work is largely experienced as for-cash labouring in low-paid labour market sectors where the spectre of exploitation and even 'modern slavery' are perpetual threats. Recent policy shifts are deepening such threats through creating increasingly 'uncomfortable' and 'hostile' environments for certain categories of migrants.

Key words: Asylum seekers, labour, exploitation, modern slavery, hostility.

\section{Asylum and the labour market: the policy context}

This article examines the relationship in the UK between asylum-seeking and the labour market. It will explore the experiences of both asylum-seekers and refused asylumseekers. As such, the article is framed in an understanding of the inter-relationship between irregular migration and asylum. Refused asylum-seekers are part of the irregular population; but also some people who are refugees in the broader sense may enter the UK through other migration channels and later become irregular, sometimes without knowing about or exercising their right to claim asylum based on a well-founded fear of persecution. It is pertinent to note that immigration categories and socio-legal statuses are not fixed for any one individual - there is a slipperiness and complexity to people's immigration trajectories through time as they move between statuses, either agentically or as a consequence of structural barriers (Düvell and Jordan, 2002; Koser, 2010; Bloch et al., 2011).

Since 2002, asylum-seekers have not been allowed to work unless they have waited over twelve months for an initial decision on their asylum claim (and in such cases are restricted to working in areas on the government's highly limited 'shortage occupation list' - current examples being skilled classical ballet dancers, tunnelling engineers meaning in practice that it is very rare for asylum-seekers to take up employment) (Waite et al., 2015a). Refused asylum-seekers have no right to work (unless they cannot be 
returned to their country of origin in line with asylum-seeker policy). Permission to work was removed by the Government in 2002 as employment was considered a 'pull factor' responsible for a growing number of asylum applications as economic migrants sought to come to the UK and to claim asylum in order to access the labour market. This pull factor thesis' (Mayblin, 2016) has become cemented in successive governments policy despite being widely discredited by researchers looking at asylum-seekers' host countries and destination choice and associated economic rights (e.g. Robinson and Segrott, 2002; Toshkov, 2014; Valenta, 2015). The outcome of the dominant pull factor thesis is that there appears no immediate political desire to reinstate the right to work for asylum-seekers, despite much campaigning and advocacy energy in this realm at certain points in time since $2002 .^{1}$

A further issue of importance to this article's focus is of course the context of Brexit. Although the focus on Brexit and immigration has predominantly been on EU migrant workers in the UK, it is clear that Brexit is also going to have notable impact on asylum law and policies. For example, this is likely to cover implications for the Common European Asylum System, and possibilities for the UK to further reduce reception conditions once it is exempt from the Reception Conditions Directive, plus removal of the EUfunded Asylum, Migration and Integration Fund, which in part funds Migrant Help (a UK based NGO) to assist those fleeing persecution to navigate the complex asylum system and access statutory support. Beyond direct asylum law and policy changes, Brexit is further likely to impact more broadly on the lives of refugees, asylum-seekers and other irregular migrants living in the UK. Alongside the worrying indications already seen of growing xenophobic rhetoric, hostility and harassment directed towards anyone labelled an 'immigrant' (Forster, 2016), there are also unresolved questions over labour market access for non-UK citizens. If the precise terms of Brexit end up curtailing EU migrants' access to the UK labour market, this is likely to reduce the supply of unskilled labour into the economy. There may therefore be increased available employment for asylum-seekers and refused asylum seekers in the medium to long term. However, with their right to work still denied, there is arguably greater chance of exploitation within low-paid/low-skilled areas of the economy as working will continue to be constructed as 'illegal' with all its associated risks of exploitation by unscrupulous employers (see the section on 'the emerging terrain of 'discomfort' and 'hostility" for more detailed policy discussion).

Following this brief introduction into the policy context of the intersections between asylum and the labour market, the next section proceeds empirically to demonstrate how asylum-seekers are sucked into survival-related work and experience subsequent exploitation. The following section furthers our understanding of the lives of vulnerable migrants in the labour market through cataloguing the damaging measures within recent immigration policies that serve to create increasing 'discomfort' and 'hostility' for certain categories of migrants. The article finishes with some concluding thoughts.

\section{Survival-related work and exploitation}

There are now many studies that attest to poverty and destitution being commonly experienced by asylum-seekers and refused asylum-seekers in the UK (Allsopp et al., 2014). The high incidence of destitution in particular amongst refused asylum-seekers due to the intentional restriction of their rights (Refugee Action, 2006; Smart, 2009) is described by the Joint Committee on Human Rights (2007) as a practice of state-enforced destitution. 
Faced with street homelessness, this article finds that such enforced destitution leads to survival-oriented livelihood activities - the seeking of paid work - for refused asylumseekers and also some asylum-seekers. Entering work which is at the outset, or becomes, severely exploitative is part of the terrain of survival traversed by such individuals.

This section of the article draws on project called Precarious Lives ${ }^{2}$ looking at experiences of labour exploitation amongst asylum-seekers and refugees in Yorkshire and Humber, in the UK. In-depth interviews were undertaken in 2011-12 with thirty people who had made a claim for asylum and who had experiences of labour that met one or more of the International Labour Organisation's indicators of forced labour, involving practices such as the withholding of wages, the threat of denunciation to authorities, debt bondage, excessive working hours or confinement to the workplace. The methodology involved a qualitative approach (due to the hidden nature of the research topic and population) utilising in-depth/biographical interviews with refugees and asylum-seekers and semi-structured interviews with practitioners and policy-makers. Throughout the article, interviewees are referred to by a pseudonym of their choice.

The reported labour exploitation experiences ranged across a number of employment sectors - typically making or serving fast food, domestic work, factory packing, care work, cleaning and food processing. It is important to emphasise that these jobs covered both informal and formal employment relationships, with some being traditional 'jobs', entered into as formal employment with a recognised employer. Yet informal waged work accounted for over half the reported experiences, where people worked with the expectation of 'cash in hand' with little if any verbal agreement or assurances of conditions.

Although not exclusively, labour exploitation for those in the asylum system is frequently experienced in periods after asylum refusal (those working and experiencing exploitation whilst seeking asylum is less common, but still experienced by some: see below). Some refused asylum-seekers enter the paid labour market as an absolute last resort, a survival-related decision contingent on declining choices in a tunnel of entrapment' (Morgan and Olsen, 2009) that ends in destitution:

It was after that [refusal] that I felt myself very desperate to survive ... I had to work to stay alive - to live - and I didn't have an alternative choice. (Parviz)

Yet others in our research took up work because of the competing pressures to make urgent remittances to families back home, to raise funds for legal representation to launch an asylum appeal or fresh claim, to avoid exhausting limited resources and to contribute to 'hosting' struggling families. What was commonly experienced by the refused asylumseekers in our sample were the various types of exploitation encountered when creative ways to survive were sought in the absence of the right to work or access to welfare.

So how exactly do refused asylum-seekers access employment when legally denied the right to work? There are overlaps here with research on the undocumented migrant population (Bloch et al., 2009; McKay et al., 2009; Valentine, 2010; Sigona, 2012) of which refused asylum-seekers are a significant part. Echoing others' findings, we found refused asylum-seekers often have a greater dependence on co-ethnic/co-language employers when seeking out work (Bloch, 2014). Yet some individuals in our sample, out of fear of denunciation, felt unable to search for jobs from within their co-ethnic/ language circles and instead turned to trudging the streets in order to access work. We see here how Rose took her chances and began tidying rubbish and clearing outside a pub: 
Because in Africa if you ... want to find a work, you do it and then they will pay you money ... He called me in his pub ... I explained to him why I was trying to clear his garden to get a bit of money to eat ... He told me when there is anything to do, cleaning or sweeping I can come and they will give me some money.

Routes into work therefore frequently rely on informal channels, whether within known-networks or not, and on workplaces willing to take on workers without requisite papers. Situations where the employer knew the worker was unauthorised were exceptionally risky for the refused asylum-seekers in our research. Common experiences of exploitation such as the imposition of excessive working hours, withheld pay or various abusive working and living conditions, were achieved by the employer's instrumental use of refused asylum-seekers' precarious socio-legal status. This was a predominant tool of coercion used to discipline workers who had 'no real and acceptable alternative' but to comply. Jay, a refused asylum-seeker, who worked intermittently for an agency, here describes violence, abuse and employer impunity:

A big bloke who used to drive the van, if you complain, you get one slap you know ... Most of the time he say to me 'You are a foreigner, there is nothing you can do here' ... What will I say? If I don't work and money to pay my accommodation I'm going to end up living in the streets.

Our interviewees consistently linked the exploitation they experienced directly to two principal aspects of their compromised socio-legal status: the 'doctrine of illegality' that makes it near-impossible for those working without authorisation to exercise any employment rights; and the risk of deportation and broader experiences of 'deportability in everyday life' (De Genova, 2002) that operate to constrain choices and discipline workers within labour relations. All of those who worked without authorisation either assumed, or knew, that their 'illegal' status left them compromised without the power to challenge their employers.

This sense of powerlessness generally meant that workers did not challenge exploitative practices as they arose. If workers did attempt to negotiate better pay or conditions, they were swiftly reminded of their expendability in a context of other undocumented workers waiting in the wings. These experiences point to common employer practices of deliberately employing unauthorised workers for the worst and most under-paid tasks. Refused asylum-seekers' desire to continue in work that might be considered severely exploitative must be understood in the wider perspective of pure survival through seeking a livelihood. The fear of losing work and the associated risks of homelessness, destitution or inability to support family members operated as an effective barrier to leaving exploitative labouring situations. In many cases, the refused asylumseekers in our study worked hard to access work and were terrified of losing their job.

Although most asylum-seekers waiting for their case to be heard did not work for fear of compromising their case, some felt compelled to seek work. After escaping one situation of prolonged withheld pay in informal child care work, Tino claimed asylum but was dispersed away from his son. In order to maintain contact, he felt driven to find cash work to supplement poverty-level asylum support payments to pay for travel to see his son (The Children's Society, 2013; Pettitt, 2013). Subsequently, his wages from his glass collecting job were withheld. A further example is provided by Hussein, who 
had permission to work as an asylum-seeker, ${ }^{3}$ but when employers failed to recognise this type of work document he was pushed into informal and often exploitative labour, travelling around in search of work to support himself - often in backroom kitchen work - rather than rely on asylum support payments. These individuals found their ability to negotiate for improved conditions was drastically reduced as their employers had knowledge of their 'illegal working', which they consequently deployed as a threat. The threat of denunciation and deportation operated in both direct and indirect ways as a disciplining device in exploitative working relations.

This section is therefore couched in a broader understanding of how the increasingly normalised techniques of state power, such as detention and deportation, discipline refused asylum-seekers, among a broader target group of undocumented migrants (Bloch and Schuster, 2005; Gibney, 2008). As De Genova (2002: 438) has argued, the disciplinary operation of state apparatus for the 'everyday production of migrant "illegality"' was never simply intended to achieve the putative goal of deportation, as it is 'deportability, and not deportation per se, that has historically rendered undocumented migrant labour a distinctly disposable commodity'. It is this idea of an ever-increasingly disposable and exploitable population of vulnerable migrants in the face of new policy measures that is the focus of the next section.

\section{The emerging terrain of 'discomfort' and 'hostility'}

The desire to make certain migrants uncomfortable has recently appeared in both UK policy and rhetoric around immigration, particularly irregular immigration. The idea that this can somehow dissuade potential new arrivals from travelling or encourage those already here to leave is a particularly familiar belief contained in deterrence policies aimed at people seeking asylum. These policies have included the 'four Ds of deterrence' (Webber, 2004) - dispersal, detention, deportation and destitution - together with the removal of the right to work and effective denial of access to public funds for refused asylum-seekers.

These principles have been made most clear in the Immigration Acts of 2014 and 2016 (see below) which hold up the creation of a 'hostile environment' as their explicit goal; as stated by then Home Secretary Theresa May in 2013 (Travis, 2013). The principles of discomfort and hostility are not new, having been central features of successively restrictive immigration policies, certainly over the last two decades and arguably since the 1905 Aliens Act. What is distinctive is that the recent Coalition and current Conservative governments have been strident in emphasising hostility as an intentional outcome of their immigration policies. With the 2015 Conservative general election victory, we are now arguably seeing a renewed zeal for, and zenith of achievement in, immigration restrictionism that revolves around the creation of discomfort and hostility.

This final section of this article, then, seeks to outline a concern that the creation of 'discomfort', targeted particularly at irregular migrants, has played, and will continue to play, an important role as a facilitator of exploitative labouring conditions for refused asylum-seekers and asylum-seekers. The precise mechanisms through which this will occur are contained in various measures in the recent Immigration Acts of 2014 and 2016. The former streamlined the removals and appeals system, making it easier and quicker to remove those held to have no right to be in the UK, whilst the latter focussed on three main areas: (i) dealing with exploitation of low-skilled workers both by increasing 
the penalties for employing 'illegal workers' and those working illegally; (ii) preventing irregular migrants from accessing services such as privately rented accommodation, bank accounts, and driving licences; and (iii) making it easier to remove people from the UK if they do not have a valid immigration status, including by extending the use of electronic tagging, restricting appeal rights, and increasing immigration officers' powers. These changes collectively enhance the susceptibility of certain migrants to workplace exploitation; acting as they will to intensify and deepen situations colleagues and I have elsewhere termed as 'hyper-precarious' (Lewis et al., 2014). This hyper-precarity will emerge particularly through new measures in the Immigration Acts targeting vulnerable migrants in the four realms of: 'illegal' working, housing, financial resources (banking) and healthcare. I will cover each in turn.

First, 'illegal' working - in announcing the Immigration Bill 2015 as a 'radical' crackdown on immigration, David Cameron emphasised proposed measures to create a stand-alone illegal working criminal offence, with a maximum penalty of a fiftyone-week prison sentence and an unlimited fine. Other measures in this battery allow immigration officials wide-ranging powers to seize property and earnings, to enter and search properties and to close down businesses. As noted by Bloch and McKay (2015), such measures have, until now, been reserved for terrorist cases. Although some of the measures are directed at employers (e.g. increased sanctions), they are likely to materially affect workers who may become more exploited through employers seeking to manage risks by lowering wages and/ or increasing working hours.

Unauthorised workers themselves, who face having their wages seized and becoming criminalised for the new offence of 'illegal working', would also face deportation without appeal if they did not have leave to remain in the UK. The principle of 'deport now, appeal later' could have profound implications for those under genuine fear of persecution in their country of origin. In our Precarious Lives research, three people had been criminalised for using a false instrument, yet two of them went on later to be granted refugee status through the appeals procedure, which recognised that they needed protection. Such routes will be highly unlikely now.

The proposal to seize the wages of 'illegal workers' is likely to direct irregular migrants into even riskier parts of the labour market (e.g. reliance on transactional and wageless labour), where the chances of detection are deemed less but severe exploitation is likely to deepen. Don Flynn (2015), of the Migrants' Rights Network, notes that 'Mr Cameron seems to want British police officers to go rifling through the purses and wallets of people suspected in breach of the rules to seize whatever cash they have on them as the "proceeds of crime". This is not money earned by robbery or fraud: it is all too often the meagre earnings from long hours or work in exploitative workplaces.' In the sense of viewing the consequences of wage seizing, it is hard to see how the removal of wages of irregular migrants can be understood as anything other than state-sanctioned facilitation of exploitation.

Secondly, housing - the 'Right to Rent' scheme in the Immigration Act 2014 obliges landlords to see evidence of a person's right to remain in the UK by examining their passport or biometric residence permit. Although rogue landlords are the intended recipients, as with many similar hostile policy proposals, it will be the migrant population that suffers. An independent evaluation of a pilot scheme of this policy in the West Midlands by the Joint Council for the Welfare of Immigrants (JCWI) (2015) shows clear evidence of discrimination emerging from landlords towards non-British passport holders, 
and even those with foreign accents or names. Irregular migrants in particular then will be confronted with the sharp end of racist and prejudicial behaviour from landlords, and will be more likely to be pushed into situations where street-homelessness and destitution looms. Overall, they will find it increasingly hard to secure rented accommodation under the 'Right to Rent' scheme. Facing genuine fears of return to country of origin persecution, refugees may feel they have 'no real or acceptable alternative' but to turn to less-detectable informal lodgings. This will in turn bring possible transactional labouring experiences that - alongside the aforementioned destitution - are highly likely to act as a driver for entry into exploitative labouring conditions when accepting 'work at any cost' comes to the fore (see also Waite and Lewis, 2017). Additionally, in regulations within the Immigration Act 2016 most likely to come into force around April 2017, there are a complex range of changes proposed for provisions to support and accommodate families and children if their asylum claim is refused. There is great concern that the complexity of legal obligation across the Home Office and local authorities will heighten the risk of vulnerable adults and children falling through the gaps between various systems (Harvey, 2016).

Thirdly, financial resources - the Immigration Act 2014 disqualified irregular migrants from opening a bank account in the UK. The new Immigration Act 2016 builds on these measures, through a requirement for banks to check the immigration status of all account holders and report on customers potentially breaching immigration controls. However, it was already very difficult for someone without 'leave to remain' to open a bank account in the UK, and use of constructed or borrowed documents to do so was already covered by fraud legislation. It is not therefore clear what the changes will introduce apart from the likelihood of widespread discrimination as bank personnel have to identify anyone they think could be a foreign national for checks, as in the case of the landlord checks.

Findings from Precarious Lives indicate that not having a bank account is a risk factor that can contribute to susceptibility to exploitation as workers do not have control over their own money, especially if their wages are paid directly into a bank. This can facilitate a type of third party exploitation - not of the kind featuring organised labour intermediaries or gangmasters frequently invoked in these labourscapes - but of a very informal and personal kind. In many instances, the co-use of a bank account is a risky activity for irregular migrants as it can make them vulnerable to losing control over their wages (Burnett and Whyte, 2010) and being sucked further into highly exploitative labour relations.

Fourthly, healthcare - in terms of health, the first point to note is that all of our interviewees talked about how their working lives had resulted in psychological and physical damage. As discussed by Burnett and Whyte (2010), the risks of irregular work are heightened incidences of injuries through questionable health and safety protection in the informal sector work, coupled with reluctance to access health services due to fear of being detected by the authorities. Health workers - more so than any other type of public agency - have insights into people's personal situations which can allow them to detect the worst forms of abuse. We found in our research that this detection contributed in a number of cases to sustainable exit from abusive and violent relationships within forced labour.

However, the reluctance already seen of irregular migrants to seek health care has not improved under The Immigration Act 2014 and subsequent secondary legislation. This saw the introduction of an annual Immigration Health Surcharge (of $£ 150-200$ for nationals outside the European Economic Area who intend to stay in the UK longer than six months). There is also great concern about the extent to which data on chargeable patients is shared with the Home Office; for example in 2014 the Home Office launched a 
series of communication measures to target irregular migrants, including the introduction of posters in all NHS services reminding patients that they may need to prove their right to reside to receive treatment (Jones et al., 2015). Commenting on these measures, Bowsher et al. (2015: 853) conclude that, '[B]y requiring general practitioners to take on the burden of assessing immigration status, this legislation has the potential to erode the foundations of modern medical practice based on confidentiality, compassion, and care for the patient and public as a whole.'

Further, in late 2015, the Department of Health announced a consultation on their new proposals to extend charging in primary care, ambulance services and Accident and Emergency departments. The Department of Health has said people seeking asylum and refugees will be exempt from charging procedures, but all refused asylum-seekers, and other irregular migrants, will be chargeable. It is highly likely, therefore, that the new health deterrence measures will deter, actively exclude or wrongly refuse (due to complex categories of migrants within those subject to the surcharge) the most vulnerable groups from receiving health-care services. Apart from the obvious negative health outcomes, the policy will also act as a deterrent to individuals potentially exiting damaging work situations, as opportunities for exit will be missed by non-presentation before health professionals.

\section{Conclusion}

As such, the Immigration Acts of 2014 and 2016 are sweeping and extensive in terms of the implications for vulnerable migrants in the realms of 'illegal' working, housing, financial resources and healthcare. While the erosion of core rights to justice, welfare, work and residency have fundamentally weakened the position of asylum-seekers and refused asylum-seekers in the UK over several decades, ${ }^{4}$ current policies are highly restrictive by intent and target quotidian practices and spaces as places of enforcement. It is this emergent swirling mix of enforcement through 'everyday bordering' (Aliverti, 2015; Yuval-Davis et al., 2017) and hostile governmentality that is producing a growing susceptibility to highly exploitative - and sometimes forced - labour for people in the asylum system. This increase in exploitation for vulnerable migrants is strikingly contradictory with government claims to rid the UK of the 'scourge of modern slavery' (May, 2014) through the Modern Slavery Act, 2015.

If we are to address this contradiction, we must first and most importantly continue to campaign and advocate for returning the right to work for asylum-seekers. I would further note the government's damaging cutting of resources and/or powers available to enforcement bodies such as the Gangmasters and Labour Abuse Authority, HM Revenue and Customs and the Employment Agency Standards Inspectorate. This direction of travel must be halted, and instead we should see a commitment to better regulate the labour market to prevent employers exploiting cheap labour. Trade unions and other organisations involved in protecting workers' and migrants' rights must also be supported in their efforts to inform workers of their rights and prevent them being exploited by employers. It is also worth endorsing the TUC's calls for industry-level wage setting institutions, such as modern wages councils, as they can play an important part in eradicating exploitation (TUC, 2016).

I conclude by returning to the issue of Brexit raised in the opening section of this article. As Lucy Mayblin (2016) has recently written with great concern, 'leaving the 
EU will lift some of the obligation to improve standards for asylum-seekers and the hostile environment is likely to be developed in new directions.' Further, the government announced (1 October 2016) an Independent Review of Employment Practices in the Modern Economy. In the Review's quest to gather evidence of the 'modern labour market', it is essential that voices attesting to widespread exploitation of vulnerable migrant workers at the margins of our economy, such as Jay, Rose and Parviz above, are heard (see also Waite et al., 2015b). At this unique political juncture therefore, and within the context of an increasingly restrictive asylum policy regime, it is never more critical to speak 'truth to power' and to join other voices in cataloguing the degrading treatment experienced by vulnerable migrants that is meted out by the government. I hope this article makes a modest contribution in this regard.

\section{Acknowledgements}

The research project supporting this article was funded by the Economic and Social Research Council [grant number RES-062-23-2895]. I wish to thank all the participants who agreed to be interviewed for this project, and colleagues who worked with me on this project - Dr Hannah Lewis (University of Sheffield), Dr Stuart Hodkinson (University of Leeds) and Prof. Peter Dwyer (University of York). My thanks also go to the two anonymous reviewers who provided useful feedback to help me improve this article, and the support of the Themed Section editors Gary Craig and Gina Netto. Any errors remain my own.

\section{Notes}

1 Such activity has ebbed and flowed over time, but has recently re-emerged somewhat with Alison Thewliss, SNP MP for Glasgow Central, tabling a Westminster Hall Debate on the 11 January 2017 on the topic of asylum-seekers and the right to work.

2 Economic and Social Research Council [grant number RES-062-23-2895].

3 Hussein had managed successfully to apply for the right to work as an asylum seeker due to delays in his asylum claim.

4 For example, in the realm of asylum procedures, since 1996 nine new pieces of primary legislation have been passed which have sought to make it more difficult for asylum applications to be successful. This has included restricting the definition of persecution, introducing safe country lists, and restricting asylum-seeker's access to legal aid, advice, and appeal rights (Mayblin, 2017).

\section{References}

Aliverti, A. (2015) 'Enlisting the public in the policing of immigration', British Journal of Criminology, 55, 215-30.

Allsopp, J., Sigona, N. and Phillimore, J. (2014) 'Poverty among asylum seekers in the UK: an evidence and policy review', IRIS working paper series No. 1/214, University of Birmingham, Birmingham.

Bloch, A. (2014) 'Living in fear: rejected asylum seekers living as irregular migrants in England', Journal of Ethnic and Migration Studies, 40, 1507-25.

Bloch, A. and McKay, S. (2015) Sanctioning Employers Does not Prevent Exploitation and Unfree Labour, https://www.opendemocracy.net/beyondslavery/alice-bloch-sonia-mckay/sanctioning-employersdoes-not-prevent-exploitation-and-unfree [accessed 15.01.2017].

Bloch, A. and Schuster, L. (2005) 'At the extremes of exclusion: deportation, detention and dispersal', Ethnic and Racial Studies, 28, 491-512. 
Bloch, A., Sigona, N. and Zetter, R. (2009) 'No Right to Dream'. The Social and Economic Lives of Young Undocumented Migrants in Britain, London: Paul Hamlyn Foundation.

Bloch, A., Sigona, N. and Zetter, R. (2011) 'Migration routes and strategies of young undocumented migrants in England: a qualitative perspective', Ethnic and Racial Studies, 34, 1286-302.

Bowsher, G. M., Krishnan, R. A., Shanahan, T. A. and Williams, S. K. (2015) 'Immigration Act 2014 challenges health of migrants in the UK', The Lancet, 385, 829-914.

Burnett, J. and Whyte, D. (2010) The Wages of Fear: Risk, Safety and Undocumented Work, Leeds: PAFRAS and the University of Liverpool.

De Genova, N. P. (2002) 'Migrant "illegality" and deportability in everyday life', Annual Review of Anthropology, 31, 419-47.

Düvell, F. and Jordan, B. (2002) 'Immigration, asylum and welfare: the European context', Critical Social Policy, 22, 498-517.

Flynn, D. (2015) 'New immigration bill will push irregular migrants into a system of modern day slavery', Migrants' Rights Network, http://www.migrantsrights.org.uk/news/2015/new-immigrationproposal-will-push-irregular-migrants-system-modern-day-slavery [accessed 30.11.2016].

Forster, K. (2016) 'Hate crimes soared by $41 \%$ after Brexit vote, official figures reveal', The Independent, London.

Gibney, M. (2008) 'Asylum and the expansion of deportation in the United Kingdom', Government and Opposition, 43, 139-43.

Harvey, A. (2016) The Immigration Act 2016: Seminar for Lawworks, http://www.ilpa.org.uk/ resources.php/32676/immigration-act-2016-seminar-for-lawworks-13-november-2016 [accessed 30.11.2016].

Joint Council for the Welfare of Immigrants (JCWI) (2015) 'No Passport Equals no Home': An Indepedent Evaluation of the 'Right to Rent' Scheme, London: Joint Council for the Welfare of Immigrants.

Joint Committee on Human Rights (2007) The Treatment of Asylum Seekers, Tenth Report of Session 2006-07, Vol. 1, Report and formal minutes, Joint Committee on Human Rights.

Jones, H., Bhattacharyya, G., Davies, W., Dhaliwal, S., Forkert, K., Gunaratnam, Y., Jackson, E. and Saltus, R. (2015) Go Home. Mapping the Unfolding Controversy of Home Office Immigration Campaigns, Coventry: University of Warwick.

Koser, K. (2010) 'Dimensions and dynamics of irregular migration', Population, Space and Place, 16, 181-93.

Lewis, H., Dwyer, P., Hodkinson, S. and Waite, L. (2014) 'Hyper-precarious lives? Migrants, work and forced labour in the Global North', Progress in Human Geography, 39, 580-600.

May, T. (2014) Modern Slavery Bill, London: The Stationary Office.

Mayblin, L. (2016) 'What will Brexit mean for asylum in the UK?', Open Democracy, https://www. opendemocracy.net/lucy-mayblin/what-will-brexit-mean-for-asylum-in-uk [accessed 15.01.2017].

Mayblin, L. (2017) Asylum After Empire: Colonial Legacies in the Politics of Asylum Seeking, London: Rowman \& Littlefield International.

McKay, S., Markova, E., Paraskevopoulou, A. and Wright, T. (2009) The Relationship between Migration Status and Employment Outcomes, Birmingham: Undocumented Worker Transitions.

Morgan, J. and Olsen, W. (2009) 'Unfreedom as the shadow of freedom: an initial contribution to the meaning of unfree labour', Manchester Papers in Political Economy Working Paper, University of Manchester.

Pettitt, J. (2013) The Poverty Barrier: The Right to Rehabilitation for Survivors of Torture in the UK, London: Freedom from Torture.

Refugee Action (2006) The Destitution Trap: Research into Destitution among Refused Asylum Seekers in the UK, London: Refugee Action.

Robinson, V. and Segrott, J. (2002) 'Understanding the decision-making of asylum seekers', Home Office Research Study 243, Home Office, London.

Sigona, N. (2012) "I have too much baggage": the impacts of legal status on the social worlds of irregular migrants', Social Anthropology, 20, 50-65. 
Smart, K. (2009) The Second Destitution Tally: An Indication of the Extent of Destitution among Asylum Seekers, Refused Asylum Seekers and Refugees, London: Asylum Support Partnership.

The Children's Society (2013) A Briefing from The Children's Society Highlighting the Gap between Asylum Support and Mainstream Benefits, London: The Children's Society.

Toshkov, D. (2014) 'The dynamic relationship between asylum applications and recognition rates in Europe (1987-2010)', European Union Politics, 15, 192-214.

Travis, A. (2013) 'Immigration bill: Theresa May defends plans to create "hostile environment"', The Guardian, 10 October 2013.

Trades Union Congress (TUC) (2016) Managing Migration Better for Britain, https://www.tuc. org.uk/sites/default/files/ManagingmigrationbetterforBritain.pdf [accessed 15.01.2017].

Valenta, M. (2015) 'The nexus of asylum seeker migrations and asylum policy: longitudinal analysis of migration trends in Norway', International Journal on Minority and Group Rights, 21, 371-94.

Valentine, R. (2010) Hope Costs Nothing: The Lives of Undocumented Migrants in the UK, London: Migrants Resource Centre and Barrow Cadbury Trust.

Waite, L., Dwyer, P., Hodkinson, S. and Lewis, H. (2015a) 'Refused asylum seekers as the hyper-exploited', in L. Waite, G. Craig, H. Lewis and K. Skrivankova (eds.), Vulnerability, Exploitation and Migrants: Insecure Work in a Globalised Economy, Basingstoke: Palgrave.

Waite, L., Lewis, H., Craig, G. and Skrivankova, K. (2015b) Vulnerability, Exploitation and Migrants: Insecure Work in a Globalised Economy, Basingstoke: Palgrave.

Waite, L. and Lewis, H. (2017) 'Precarious irregular migrants and their sharing economies: a spectrum of transactional labouring experiences', Annals of the American Association of Geographers, http://www.tandfonline.com/eprint/7s2ZBdXejBs8xEjqEqGn/full.

Webber, F. (2004) 'Asylum - from deterrence to destitution', Race and Class, 45, 77-85.

Yuval-Davis, N., Wemyss, G. and Cassidy, K. (2017) Bordering, Cambridge: Polity Press. 